\title{
PENERAPAN MODEL PEMBELAJARAN TEAMS GAMES TOURNAMENTS BERBANTU SISTEM REWARD CARD TERHADAP KEMAMPUAN PEMAHAMAN MATEMATIS SISWA
}

\author{
${ }^{1}$ Tiara Irawati \\ ${ }^{1}$ Pendidikan Matematika, Fakultas Keguruan dan Ilmu Pendidikan, Universitas Muhammadiyah Sukabumi \\ 1tiarairawati@gmail.com
}

\begin{abstract}
Abstrak
Penelitian ini bertujuan untuk mengetahui perbandingan kemampuan pemahaman konsep matematis antara siswa yang memperoleh model pembelajaran Teams Games Tournaments (TGT) berbantu sistem reward card dengan siswa yang memperoleh model pembelajaran Teams Games Tournaments (TGT) dan siswa yang memperoleh model pembelajaran langsung. Metode penelitian yang digunakan adalah metode kuasi-eksperimen dengan desain the nonequivalent pretest-posstest control group design.Instrumen yang digunakan yaitu soal pemahaman konsep, lemabar observasi, dan lembar validasi. Hasil penelitian ini yaitu (1) kemampuan pemahaman konsep matematis siswa dengan menggunakan model pembelajaran Teams Games Tournaments (TGT) berbantu sistem reward card lebih baik daripada kemampuan pemahaman konsep matematis siswa dengan menggunakan model pembelajaran Teams Games Tournaments (TGT), (2) kemampuan pemahaman konsep matematis siswa dengan menggunakan model pembelajaran Teams Games Tournaments (TGT) berbantu sistem reward card lebih baik daripada kemampuan pemahaman konsep matematis siswa dengan menggunakan model pembelajaran langsung, (3) tidak terdapat perbedaan antara kemampuan pemahaman konsep matematis siswa dengan model pembelajaran Teams Games Tournaments (TGT) dengan model pembelajaran langsung.
\end{abstract}

Kata kunci: model pembelajaran TGT, reward card, pemahaman konsep matematis.

\section{PENDAHULUAN}

Pembelajaran matematika selalu menjadi momok bagi kebanyakan siswa baik di jenjang SD, SLTP maupun SLTA karena matematika dianggap sulit untuk dipelajari dan matematika memang bersifat abstrak tidak seperti pelajaran lain. Hal tersebut sejalan dengan banyak permasalahan dalam pembelajaran matematika di sekolah misalnya rendahnya hasil belajar matematika (Kadir, 2012: 155). Menurut Retnowati (2012: 2) menyatakan bahwa "Fokus pada hakikat pelajaran matematika adalah pemahaman konsep”. Maksudnya pada pembelajaran matematika siswa harus memahami konsep terlebih dahulu agar dapat menyelesaikan soal-soal dan mampu mengaplikasikan pembelajaran tersebut di dunia nyata. Pada umumnya kemampuan pemahaman konsep merupakan hal yang sangat fundamental dalam pembelajaran matematika agar belajar menjadi lebih bermakna (Kadir, 2012: 210).

Berdasarkan hasil wawancara pada tanggal 25 Januari 2017 dengan salah satu guru di Sekolah Menengah Pertama Negeri 7 Kota Sukabumi permasalahan yang sering di hadapi dalam pembelajaran matematika yaitu pemahaman konsep siswa yang masih rendah. Ini dapat ditunjukkan dari data hasil ulangan harian pada materi aritmatika sosial tahun pelajaran 2016/2017 kelas VII di Sekolah Menengah Pertama Negeri 7 Kota Sukabumi, dari 2 kelas dengan jumlah siswa 59 hanya sekitar 16 orang yang mendapat nilai 60 ke atas dan sisanya di bawah 60. Dapat ditarik kesimpulan dari data tersebut bahwa penyebab rendahnya hasil ulangan harian yaitu pemahaman siswa terhadap konsep masih sangat rendah. Ulangan harian memiliki indikator - indikator pemahaman konsep, contohnya soal no. 1 yaitu "Harga 35 buku Rp. 122.500 untuk membeli 24 buku tersebut diperlukan uang sebanyak ?" ini merupakan indikator pemahaman konsep yaitu menerapkan konsep secara algoritma.

Sejalan dengan itu menurut Susanto (2013: 208) menyatakan bahwa pemahaman merupakan hasil dari proses pembelajaran. Pada proses pembelajarannya pun masih didominasi oleh guru sehingga kebanyakan siswa sangat pasif dalam merespon pembelajaran suatu materi. Pada pelaksanaan proses pembelajaran di sekolah kebanyakannya masih menggunakan model pembelajaran langsung. Hasil penelitian Fauziah (2010: 2) menyatakan bahwa "pembelajaran yang dilakukan dengan metode ceramah menyebabkan siswa menjadi pasif pada saat proses pembelajaran". Berdasarkan uraian tersebut kesulitan memahami konsep matematika dikarenakan beberapa faktor diantaranya penggunaan model pembelajaran yang masih berkonsep ceramah, tidak menarik sehingga menimbulkan partisipasi siswa di dalam kelas pasif, hanya berpusat pada guru tanpa siswa diberi kebebasan aktif dalam suatu proses pembelajaran. Berdasarkan uraian tersebut proses pembelajaran terkesan kaku hanya berfokus pada materi dan guru.

Sejalan dengan pendapat di atas menurut Susanto (2013: 208) model pembelajaran yang hanya terfokus pada pemberian pengetahuan berupa teori-teori lalu 
menyimpannya dalam memori merupakan proses pembelajaran yang tidak bermakna dan tidak efektif. Untuk mengatasi masalah tersebut, perlu adanya peran dari siswa dan guru agar kemampuan pemahaman konsep siswa meningkat ke level yang lebih baik dari sebelumnya. Pada segi pemahaman siswa perlu ditingkatkan sehingga siswa dapat menyelesaikan berbagai pemecahan masalah baik masalah di dalam pembelajaran matematika maupun di luar aspek matematika. Karena pemahaman dan penguasaan suatu materi atau konsep merupakan prasyarat untuk menguasai konsep selanjutnya (Susanto, 2013: 209). Perlu adanya pembaharuan dalam proses pembelajaran dengan menggunakan model-model pembelajaran yang menarik dan inovatif .

Upaya untuk melatih pemahaman konsep siswa dalam pembelajaran matematika perlu disusun suatu model pembelajaran yang dapat meningkatkan keaktifan serta keterlibatan dalam proses pembelajaran yaitu dengan model pembelajaran kooperatif (Musdi, dkk 2014: 2). Sesuai dengan pemaparan di atas masalah mengenai rendahnya pemahaman konsep matematis dapat diatasi dengan menggunakan model pembelajaran kooperatif. Model pembelajaran kooperatif memiliki tujuan untuk penguasaan pengetahuan akademik, penerimaan terhadap keragaman dan pengembangan keterampilan sosial (Sani, 2014: 132). Adanya keterkaitan permasalahan rendahnya pemahaman konsep dengan model pembelajaran yang dipakai. Sejalan dengan hasil penelitian Fauziah dan Situmorang yang telah dipaparkan di atas apalagi proses pembelajaran masih menggunakan model pembelajaran langsung yang berpusat pada guru (active teaching) dan tidak menggunakan model pembelajaran yang menarik maka imbasnya kepada kemampuan matematis siswa yang akan tetap rendah tidak mengalami peningkatan dari segi pemahaman siswa. Untuk menghindari hal tersebut perlu adanya solusi yang mendukung dengan penerapan proses pembelajaran yang menarik dengan model pembelajaran kooperatif. Pembelajaran kooperatif adalah salah satu pembelajaran yang menuntut siswa untuk aktif, kreatif, dan berlatih kemampuan bekerjasama, serta kemandirian (Purnamasari, 2014: 2).

Salah satu model pembelajaran kooperatif yang bisa dijadikan alternatif adalah model pembelajaran Teams Games Tournaments (TGT). Menurut Lestari dan Yudhanegara (2015: 47) model pembelajaran Teams Games Tournaments (TGT) adalah salah satu tipe pembelajaran kooperatif yang menitikberatkan permainan dan turnamen untuk mencapai ketuntasan. Model pembelajaran Teams Games Tournaments (TGT) yang mudah diterapkan dan mengandung unsur permainan sehingga dapat membangkitkan minat siswa pada pembelajaran matematika (Hamid, 2011: 3). Salah satu kelebihan model pembelajaran Teams Games Tournaments (TGT) yaitu cara diskusi yang akan lebih mudah menemukan dan memahami konsep-konsep yang sulit (Nugroho dan Rachman, 2013: 162).

Selain itu, dengan bantuan pemberian sistem reward card dinilai dapat memacu kemampuan pemahaman matematis siswa ke taraf yang lebih baik dan pada proses pembelajarannya pun akan menarik juga inovatif karena berbasis games yang akan disukai siswa (Hamid, 2011: 3). Sistem reward card dinilai menjadi inovasi baru dalam proses pembelajaran pembelajaran matematika hal tersebut bisa dikatakan karena belum ada penelitianpenelitian sebelumnya mengenai sistem reward card. Pemberian sistem reward card dinilai dapat mendorong motivasi dan minat siswa terhadap pembelajaran matematika sehingga pada pelaksanaan proses pembelajaran berlangsung dengan antusiasme siswa agar dapat menyelesaikan soal soal yang diberikan guna mendapatkan point plus. Karena pada prosedur sistem reward card ketika siswa dapat menjawab setiap soal baik latihan, tugas maupun tes individu maka siswa tersebut akan diberikan point plus yang secara berkala. Secara tidak langsung siswa diberikan stimulus untuk menguasai suatu konsep tanpa adanya tekanan psikologis dalam dirinya. Kelebihan sistem reward card yaitu mendorong siswa untuk terus belajar. Hal ini dinilai dapat mendorong penguasaan konsep baik. Maka dari itu, penelitian ini menggunakan model pembelajaran kooperatif tipe Teams Games Tournaments (TGT) dengan bantuan sistem reward card.

Rumusan masalah dalam penelitian ini sebagai berikut. 1) Apakah kemampuan pemahaman konsep matematis siswa dengan model pembelajaran Teams Games Tournaments (TGT) berbantu sistem reward card lebih baik daripada model pembelajaran Teams Games Tournaments (TGT)? 2) Apakah kemampuan pemahaman konsep matematis siswa dengan model pembelajaran Teams Games Tournaments (TGT) berbantu sistem reward card lebih baik daripada model pembelajaran langsung?

Tujuan penelitian ini sebagai berikut : 1) Untuk mengetahui perbandingan kemampuan pemahaman konsep matematis antara siswa yang memperoleh model pembelajaran Teams Games Tournaments (TGT) berbantu sistem reward card dengan siswa yang memperoleh model pembelajaran Teams Games Tournaments (TGT). 2) Untuk mengetahui perbandingan kemampuan pemahaman konsep matematis antara siswa yang memperoleh model pembelajaran Teams Games Tournaments (TGT) berbantu sistem reward card dengan siswa yang memperoleh model pembelajaran langsung.

Manfaat penelitian ini hasil penelitiannya mengenai model pembelajaran Teams Games Tournaments (TGT) 
berbantu sistem reward card dapat menjadi salah satu rujukan untuk memperkaya dunia pendidikan dan dapat menambah wawasan ilmu pengetahuan, sebagai usulan positif bagi guru matematika.

\section{METODE}

Desain penelitian yang digunakan dalam penelitian ini adalah the nonequivalent pretest-posttest control group design artinya desain kelompok kontrol pretest-posttest tidak ekuivalen. Pada desain ini diberikan pretest terlebih dahulu sebelum dilakukan perlakukan gunanya untuk mengetahui keadaan awal. Keadaan awal yang dimaksud dalam penelitian ini adalah kemampuan awal pemahaman konsep matematis siswa. Setelah mendapat perlakuan yang berbeda ditiap kelas di akhir penelitian diberikan posttest untuk melihat bagaimana hasil akhir kemampuan pemahaman konsep matematis siswa (Lestari dan Yudhanegara, 2015: 46). Sampel dibagi menjadi tiga kelompok, yaitu dua kelas eksperimen dan satu kelas kontrol.

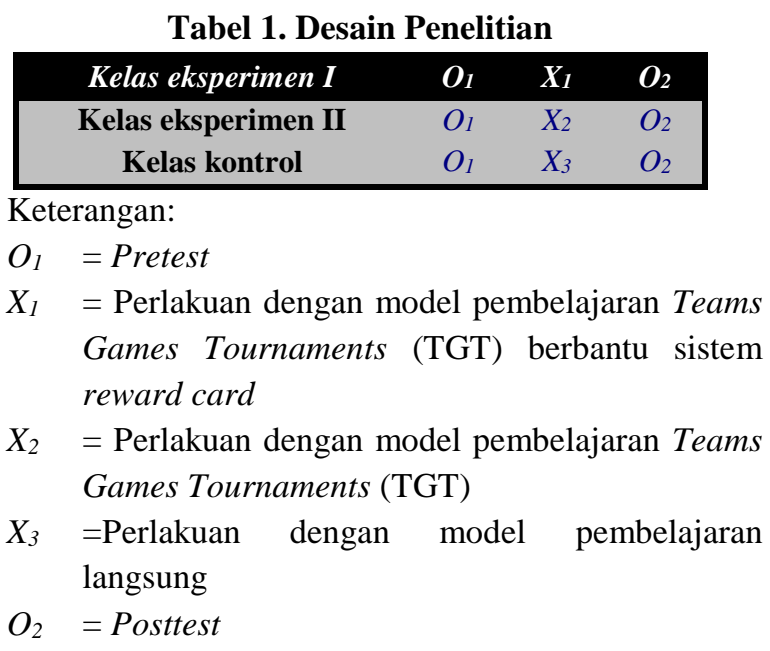

Populasi dalam penelitian ini adalah seluruh siswa kelas VII Sekolah Menengah Pertama Negeri 7 Kota Sukabumi tahun pelajaran 2016/2017 yang berjumlah 180 siswa dan terbagi ke dalam 6 kelas. Penentuan sampel yang akan dilakukan dengan sampel random atau acak. Teknik pengambilan sampel yang digunakan dalam penelitian ini adalah cluster random sampling/area random sampling, yaitu pengacakan sampel daerah. Cluster random sampling/acak kelas dapat dilakukan jika kelas dalam populasi yang akan diambil sebagai sampel memiliki karakteristik yang homogen/relative homogen/ tidak ada kelas unggulan (Lestari dan Yudhanegara, 2015: 105).

Cara pengambilan ketiga kelas tersebut menggunakan undian, untuk undian pertama menjadi kelas eksperimen I dengan perlakuan model pembelajaran Teams Games Tournaments (TGT) berbantu sistem reward card, undian ke dua menjadi kelas eksperimen II dengan perlakuan model pembelajaran Teams Games Tournaments (TGT), dan undian yang ketiga menjadi kelas kontrol dengan perlakuan model pembelajaran langsung.

Teknik pengumpulan data ada 3 macam yaitu 1) Dokumentasi 2) Metode observasi 3) Metode tes. Istrumen ydigunakan dalam penelitian ini yaitu tes pemahaman konsep, lembar observasi, dan lembar validasi.

Langkah-langkah pada metode tes (Lestari dan Yudhanegara, 2015: 105) sebagai berikut:

a. Menentukan indikator dari variabel yang diteliti dalam penelitian;

b. Menyusun kisi-kisi instrumen;

c. Menentukan kriteria penskoran/penilaian;

d. Merumuskan item-item pertanyaan atau pernyataan;

e. Melakukan uji coba instrumen;

f. Memberikan penskoran/penilaian;

g. Melakukan analisis hasil uji coba instrumen;

h. Menentukan instrument yang akan digunakan dalam penelitian.

Data hasil uji coba instrument selanjutnya yaitu uji validitas isi, reabilitas, tingkat kesukaran, dan daya pembedanya. Teknik analisis data yang digunakan untuk pretest yaitu uji prasyarat (uji normalitas dan uji homogenitas) serta uji keseimbangan sedangan untuk data posttest uji prasyarat (uji normalitas dan uji homogenitas) serta uji anava satu jalur dilanjut uji pasca anava.

\section{HASIL DAN PEMBAHASAN}

\section{Deskripsi Hasil Kemampuan Akhir Pemahaman Konsep Matematis (Pretest)}

Data tentang kemampuan awal pemahaman konsep matematis siswa diperoleh dari hasil pretest materi garis dan sudut. Data awal ini gunanya untuk mengetahui kemampuan pemahaman konsep matematis siswa ketiga kelas yang diambil memiliki kemampuan yang sama.

Berdasarkan hasil perhitungan diperoleh hasilnya yaitu untuk kelas eksperimen I memperoleh $\mathrm{L}_{\text {hitung }}=$ 0,104 dengan $\mathrm{L}_{\text {tabel }}=0,161$. Karena $\mathrm{L}_{\text {hitung }}<\mathrm{L}_{\text {tabe }}$, maka $\mathrm{H}_{0}$ diterima. Sehingga dapat disimpulkan bahwa kelas eksperimen I berasal dari populasi yang berdistribusi normal.Untuk kelas eksperimen II hasil perhitungan diperoleh $\mathrm{L}_{\text {hitung }}=0,089$ dengan $\mathrm{L}_{\text {tabel }}=0,161$. Karena $\mathrm{L}_{\text {hitung }}<\mathrm{L}_{\text {tabel }}$, maka $\mathrm{H}_{0}$ diterima. Sehingga dapat disimpulkan bahwa kelas eksperimen II berasal dari populasi yang berdistribusi normal. Sedangkan hasil perhitungan kelas kontrol diperoleh $\mathrm{L}_{\text {hitung }}=0,152$ dengan $\mathrm{L}_{\text {tabel }}=0,161$. Karena $\mathrm{L}_{\text {hitung }}<\mathrm{L}_{\text {tabel }}$, maka $\mathrm{H}_{0}$ diterima. Sehingga dapat disimpulkan bahwa kelas kontrol berasal dari populasi yang berdistribusi normal.

Berdasarkan hasil perhitungan diperoleh $\mathrm{X}^{2}$ hitung $=$ 3,963 dengan $\mathrm{X}_{\text {tabel }}=5,991$. Karena $\mathrm{X}^{2}{ }_{\text {hitung }}$ berada diluar 
daerah kritis, maka $\mathrm{H}_{0}$ diterima. Sehingga dapat disimpulkan bahwa sampel berasal dari populasi bervarians homogen.

Sebelum eksperimen berlangsung dilakukan uji keseimbangan. Hal ini dimaksud agar hasil dari eksperimen benar-benar akibat dari perlakuan yang berbeda, bukan karena pengaruh yang lain. Uji keseimbangan digunakan untuk menguji rataan kelas eksperimen dan kelas kontrol. Dengan uji prasyarat analisis bahwa sampel berasal dari populasi berdistribusi normal dan homogen. Data yang digunakan dalam uji keseimbangan ini adalah data pretest. Pada penelitian ini, uji statistik yang digunakan untuk menguji keseimbangan yaitu menggunakan uji anava satu jalur dengan sel tak sama. Hasil perhitungan uji anava satu jalan dihasilkan $\mathrm{F}$ hitung $=1,335$ dengan $\mathrm{F}_{0,05 ; 2 ; 86}=3,100$, sedangkan daerah kritis $D K=\{F \mid F>3,100\}$. Ini artinya $F_{\text {hitung }}=1,335$ diluar $\mathrm{F}_{\text {tabel}}$, sehingga $\mathrm{H}_{0}$ diterima. Dengan demikian dapat disimpulkan bahwa kemampuan awal anatara kelas eksperimen I, kelas eksperimen II dan kelas kontrol mempunyai kemampuan awal yang sama.

2. Deskripsi Hasil Kemampuan Akhir Pemahaman

\section{Konsep Matematis (Posttest)}

Data ini diperoleh dari hasil posttest kemampuan pemahaman konsep matematis yang diperoleh setelah dilakukan perlakuan, untuk kelompok siswa yang belajar dengan model pembelajaran Teams Games Tournaments (TGT) berbantu sistem reward card ataupun untuk kelompok siswa yang belajar dengan model pembelajaran Teams Games Tournaments (TGT) dan yang menggunakan model pembelajaran langsung.

Tabel 2. Rangkuman Hasil Uji Normalitas Kemampuan Akhir Pemahaman Konsep Matematis

Berdasarkan hasil perhitungan diperoleh hasilnya yaitu untuk kelas eksperimen I memperoleh $\mathrm{L}_{\text {hitung }}=0,122$ dengan $\mathrm{L}_{\text {tabe } 1}=0,161$. Karena $\mathrm{L}_{\text {hitung }}<\mathrm{L}_{\text {tabe } 1}$, maka $\mathrm{H}_{0}$ diterima. Sehingga dapat disimpulkan bahwa kelas eksperimen I berasal dari populasi yang berdistribusi normal. Untuk kelas eksperimen II hasil perhitungan diperoleh $\mathrm{L}_{\text {hitung }}=0,095$ dengan $\mathrm{L}_{\text {tabel }}=0,161$. Karena $\mathrm{L}_{\text {hitung }}<\mathrm{L}_{\text {tabel }}$, maka $\mathrm{H}_{0}$ diterima. Sehingga dapat disimpulkan bahwa kelas eksperimen II berasal dari populasi yang berdistribusi normal. Sedangkan hasil perhitungan kelas kontrol diperoleh $\mathrm{L}_{\text {hitung }}=0,112$ dengan $\mathrm{L}_{\text {tabel }}=0,161$. Karena $\mathrm{L}_{\text {hitung }}<\mathrm{L}_{\text {tabel }}$, maka $\mathrm{H}_{0}$ diterima. Sehingga dapat disimpulkan bahwa kelas kontrol berasal dari populasi yang berdistribusi normal.

\section{Tabel 3. Rangkuman Hasil Uji Homogenitas}

\section{Kemampuan Akhir}

\begin{tabular}{c|llll}
\hline Nama Variabel & $\boldsymbol{X}^{2}{ }_{\text {hitung }}$ & $\boldsymbol{X}_{\text {tabel }}^{2}$ & Keputusan & Ket. \\
\hline $\begin{array}{l}\text { Kelas Eksperimen I, } \\
\text { Kelas Eksperimen II } \\
\text { dan Kelas Kontrol }\end{array}$ & 0,801 & 5,991 & $\mathrm{H}_{0}$ diterima & Homogen \\
\hline
\end{tabular}

Berdasarkan hasil perhitungan diperoleh $\mathrm{X}^{2}$ hitung $=$ 0,801 dengan $X_{\text {tabel }}^{2}=5,991$. Karena $X^{2}$ hitung berada diluar daerah kritis, maka $\mathrm{H}_{0}$ diterima. Sehingga dapat disimpulkan bahwa sampel berasal dari populasi bervarians homogen.

Prosedur uji hipotesis pada penelitian ini menggunakan analisis variansi satu jalan dengan sel tak sama karena data berdistribusi normal dan homogen. Penelitian ini menggunakan analisis variansi satu jalan dengan sel tak sama karena memiliki tiga sampel yang akan diuji yaitu kelas eksperimen I yang menggunakan model pembelajaran Teams Games Tournaments (TGT) berbantu sistem reward card, kelas eksperimen II yang menggunakan model pembelajaran Teams Games Tournaments (TGT) dan kelas kontrol yang menggunakan model pembelajaran langsung dengan masing masing sampel memiliki jumlah siswa yang berbeda setiap kelasnya. Hasil perhitungan analisis variansi satu jalur sel tak sama dengan taraf signifikansi 0,05 disajikan pada tabel berikut:

\section{Tabel 4. Rangkuman Analisis Variansi Satu Jalur}

\begin{tabular}{|c|c|c|c|c|c|}
\hline $\begin{array}{c}\text { Sumber } \\
\text { Variansi }\end{array}$ & JK & dk & RK & $\mathbf{F}_{\text {hitung }}$ & Fo \\
\hline Model & 2970,100 & 2 & 1485,050 & 14,122 & 3,100 \\
\hline Galat & 9043,900 & 86 & 105,162 & - & - \\
\hline Total & 12014 & 88 & - & - & - \\
\hline
\end{tabular}

\begin{tabular}{|c|c|c|c|c|c|}
\hline No. & Sampel & Lhitung & & Keputusan & Ket. \\
\hline 1 & $\begin{array}{l}\text { Kelas } \\
\text { Eksperimen } \\
\text { I }\end{array}$ & 0,122 & 0,161 & $\mathrm{H}_{0}$ diterima & Normal \\
\hline 2 & $\begin{array}{l}\text { Kelas } \\
\text { Eksperimen } \\
\text { II }\end{array}$ & 0,095 & 0,161 & $\mathrm{H}_{0}$ diterima & Normal \\
\hline 3 & $\begin{array}{l}\text { Kelas } \\
\text { Kontrol }\end{array}$ & 0,112 & 0,161 & $\mathrm{H}_{0}$ diterima & Normal \\
\hline
\end{tabular}

Berdasarkan tabel tersebut, tampak bahwa $\mathrm{F}_{\text {hitung }}=$ 14,122 dan $\mathrm{F} \alpha=3,100$, karena $\mathrm{F}_{\text {hitung }}>\mathrm{F} \alpha$, maka $\mathrm{H}_{0}$ ditolak atau $\mathrm{H}_{1}$ diterima, $\mathrm{Hal}$ ini berarti terdapat perbedaan kemampuan pemahaman konsep matematis siswa yang menerapkan model pembelajaran Teams Games Tournaments (TGT) berbantu sistem reward card, model pembelajaran Teams Games Tournaments (TGT) dan model pembelajaran langsung

\section{Uji Komparasi Ganda}

Dari kesimpulan atau hasil penelitian perlu dilakukan komparasi ganda atau uji lanjut pasca anava untuk menentukan model pembelajaran mana yang lebih 
baik. Komparasi ganda digunakan sebagai tindak lanjut setelah uji analisis variansi dilakukan jika pada pengujian terdapat perbedaan. Komparasi ganda menggunakan metode Scheffe. Uji komparasi hanya dapat dilakukan pada hipotesis nol yang ditolak. Pada pengujian hipotesis dengan menggunakan analisis variansi satu jalur didapatkan hipotesis nol ditolak.

\section{Tabel 5. Uji Schefee’ Komparasi Antar Kolom}

\begin{tabular}{|c|rrrl|} 
Komparasi & $\mathbf{F}_{\text {hitung }}$ & $\mathbf{F} \boldsymbol{\alpha}$ & Ket. & Keputusan Uji \\
\hline$\mu_{1}$ dengan $\mu_{2}$ & 14,425 & 6,200 & $\mathrm{~F}_{\text {hitung }}>\mathrm{F} \alpha$ & $\mathrm{H}_{0}$ ditolak \\
\hline$\mu_{1}$ dengan $\mu_{3}$ & 26,124 & 6,200 & $\mathrm{~F}_{\text {hitung }}>\mathrm{F} \alpha$ & $\mathrm{H}_{0}$ ditolak \\
\hline
\end{tabular}

\section{Keterangan:}

$\mu_{1}$ :Kelas eksperimen I yang menggunakan model pembelajaran Teams Games Tournaments (TGT) berbantu system reward card

$\mu_{2}$ :Kelas eksperimen II yang menggunakan model pembelajaran Teams Games Tournaments (TGT)

$\mu_{3}$ :Kelas kontrol yang menggunakan model pembelajaran langsung

Dari rangkuman hasil uji schefee' tampak bahwa:

a. Pada $\mu_{1}$ dengan $\mu_{2}$ diperoleh keputusan uji $\mathrm{H}_{0}$ ditolak maka secara signifikan ada perbedaan antara rerata kelas eksperimen I yang menggunakan model pembelajaran Teams Games Tournaments (TGT) berbantu sistem reward card dengan rerata kelas eksperimen II yang menggunakan model pembelajaran Teams Games Tournaments (TGT). Karena $\mu_{1}=61,867$ dan $\mu_{2}=51,724$, maka $\mu_{1}$ lebih baik dari $\mu_{2}$.

b. Pada $\mu_{1}$ dengan $\mu_{3}$ diperoleh keputusan uji $\mathrm{H}_{0}$ ditolak maka secara signifikan ada perbedaan antara rerata kelas eksperimen I yang menggunakan model pembelajaran Teams Games Tournaments (TGT) berbantu sistem reward card dengan rerata kelas kontrol yang menggunakan model pembelajaran langsung. Karena $\mu_{1}=61,867$ dan $\mu_{3}=48,333$, maka $\mu_{1}$ lebih baik dari $\mu_{3}$.

Berdasarkan analisis data, untuk hipotesis pertama yang menuturkan bahwa kemampuan pemahaman konsep matematis siswa dengan model pembelajaran Teams Games Tournaments (TGT) berbantu sistem reward card lebih baik daripada model pembelajaran Teams Games Tournaments (TGT) diketahui bahwa $\mathrm{H}_{0}$ ditolak atau $\mathrm{H}_{1}$ diterima dapat dinyatakan bahwa kemampuan pemahaman konsep matematis dengan model pembelajaran Teams Games Tournaments (TGT) berbantu sistem reward card lebih baik daripada model pembelajaran Teams Games Tournaments (TGT). Hal ini disebabkan karena pada proses pembelajaran kelas eksperimen I dengan model pembelajaran Teams Games Tournaments (TGT) berbantu sistem reward card.

Reward card ini bermanfaat sebagai alat atau media untuk mengumpulkan point plus pada siswa yang aktif menjawab soal-soal yang diberikan guru sehingga dapat mengklasifikasikan siswa berdasarkan point yang mereka peroleh untuk mengetahui perkembangan pemahaman siswa terhadap mata pelajaran yang telah dipelajari serta untuk mendorong penguasaaan konsep matematis setiap siswa. Sejalan dengan teori menurut Muijs dan Reynold (2008: 140) menyatakan bahwa penggunaan point plus dapat membantu menguatkan perilaku tertentu yang diinginkan. Penggunaan reward card pada proses pembelajaran dilapangan dapat meningkatkan motivasi di samping meningkatkan pemahaman siswa, dapat mendorong siswa untuk terus menguasai konsep sehingga siswa yang lemah pemahamannya akan terpacu agar bisa paham terhadap konsep yang dipelajari, dan dapat melatih siswa untuk bekerjasama secara kelompok.

Untuk hipotesis kedua yang menuturkan bahwa kemampuan pemahaman konsep matematis siswa dengan model pembelajaran Teams Games Tournaments (TGT) berbantu sistem reward card lebih baik daripada model pembelajaran langsung diketahui bahwa $\mathrm{H}_{0}$ ditolak atau $\mathrm{H}_{1}$ diterima dapat dinyatakan bahwa kemampuan pemahaman konsep matematis dengan model pembelajaran Teams Games Tournaments (TGT) berbantu sistem reward card lebih baik daripada model pembelajaran langsung. Hal ini disebabkan karena pada penggunaan model pembelajaran langsung yang masih berkonsep ceramah dalam proses pembelajarannya sehingga tidak menarik dan menimbulkan partisipasi siswa di dalam kelas pasif, hanya berpusat pada guru tanpa siswa .

Proses pembelajaran dilapangannya pun terkesan kaku hanya berjalan satu arah yaitu dari guru ke siswa tanpa ada feedback. Sejalan dengan hasil penelitian Fauziah (2010: 2) bahwa proses pembelajaran masih menggunakan model pembelajaran langsung yang berpusat pada guru (active teaching) dan tidak menggunakan model pembelajaran yang menarik maka imbasnya kepada kemampuan matematis siswa yang akan tetap rendah tidak mengalami peningkatan dari segi pemahaman siswa. Penuturan tersebut terlihat pada proses pembelajaran yang berlangsung 5 minggu di kelas kontrol. Sedangkan pada proses pembelajaran dengan model pembelajaran Teams Games Tournaments (TGT) berbantu sistem reward card dibentuk kelompokkelompok kecil yang setiap kelompoknya diberikan lembar jawaban siswa untuk dikerjakan bersama-sama ditambah dengan pemberian sistem reward card memicu motivasi siswa yang lebih baik dan mendorong siswa untuk terus belajar. Pada proses pembelajarannya pun 
siswa aktif dan senang dengan adanya tournaments membuat siswa belajar lebih rajin karena termotivasi unuk bisa mendapatkan kelompok terbaik.

\section{PENUTUP}

\section{Simpulan}

Berdasarkan hasil analisis data dan pembahasan dapat ditarik kesimpulan sebagai berikut.

1. Kemampuan pemahaman konsep matematis siswa dengan menggunakan model pembelajaran Teams Games Tournaments (TGT) berbantu sistem reward card lebih baik daripada kemampuan pemahaman konsep matematis siswa dengan menggunakan model pembelajaran Teams Games Tournaments (TGT).

2. Kemampuan pemahaman konsep matematis siswa dengan menggunakan model pembelajaran Teams Games Tournaments (TGT) berbantu sistem reward card lebih baik daripada kemampuan pemahaman konsep matematis siswa dengan menggunakan model pembelajaran langsung

\section{Saran}

Untuk penelitian selanjutnya diharapkan agar dapat mengelola waktu dengan efektif dan efisien dalam pelaksanaan model pembelajaran Teams Games Tournaments (TGT) yang menggunakan sistem reward card dan yang tanpa menggunakan sistem reward card.

\section{DAFTAR PUSTAKA}

Fauziah, Anna. 2010.” Peningkatan Kemampuan Pemahaman dan Pemecahan Masalah Matematik Siswa SMP Melalui Strategi REACT". Forum Kependidikan. 30, (1), 1-13.

Hamid, M. S. 2011. Metode Edutaiment. Yogyakarta: Diva Press.

Kadir, Abdul. 2012. Dasar-dasar Pendidikan. Jakarta: Kencana Prenada Media Group.

Lestari, K. E. dan Yudhanegara, M. R. 2015. Penelitian Pendidikan Matematika. Bandung: Refika Aditama.

Muijs, Daniel and Reynolds, David. 2008. Effective Teaching. Yogyakarta: Pustaka Pelajar.

Musdi, dkk. 2014. "Pengaruh Pembelajaran Kooperatif Tipe Teams Games Tournament terhadap Hasil Belajar Matematika di Kelas VIII SMPN 2 Bukittinggi Tahun Pelajaran 2013/2014". Jurnal Pendidikan Matematika. 2, (3), 1-5.

Nugroho, R. D. dan Rachman, A. 2013. "Penerapan Model Pembelajaran Kooperatif Tipe Team Games Tournament (TGT) terhadap Motivasi Siswa Mengikuti Pembelajaran Bola Voli di Kelas X SMAN 1 Panggul Kabupaten Trenggalek". Jurnal Pendidikan Olahraga dan Kesehatan. 1, (1), 161-165.
Purnamasari, Yanti. 2014. "Pengaruh Model Pembelajaran Kooperatif Tipe Teams Games Tournament (Tgt) Terhadap Kemandirian Belajar Dan Peningkatan Kemampuan Penalaran Dan Koneksi Matematik Peserta Didik SMPN 1 Kota Tasikmalaya". Jurnal Pendidikan dan Keguruan. 1, (1), 1-11.

Retnowati, dkk. 2013. "Upaya Meningkatkan Pemahaman Konsep dan Disposisi Matematis Menggunakan Model Pembelajaran Treffinge". Seminar Nasional Pendidikan Matematika. 14.

Sani, R. A. 2014. Inovasi Pembelajaran. Jakarta: Bumi Aksara.

Susanto, Ahmad. 2013. Teori Belajar Pembelajaran di Sekolah Dasar. Jakarta: Kencana Prenadamedia Group. 